\title{
The New Kid on the Block: How South African Tertiary Institutions Respond to the Emerging Profession of Mechatronic Engineering
}

\author{
Quraisha Dawood \\ ORCID iD: https://orcid.org/0000-0002-6234-3792
}

\section{Mariam Seedat-Khan \\ ORCID iD: https://orcid.org/0000-0001-9056-2282}

\section{Abstract}

This paper seeks to understand how tertiary education institutions in South Africa have formulated a strategy for students embarking on a degree programme for the fledgling profession in the field of engineering, a field that is expanding in both scope and depth. Literature on the sociology of professsions connects qualification to a cultural mandate, industry demands, and accredited associations as the key determining factors for the legitimisation of a fledgling profession. Therefore, consideration is given to the aspect of a qualifications framework and how tertiary institutions understand these new professions and develop curricula for them, based on a constructivist approach to curriculum development and knowledge construction. To delve into this dynamic, the author focus on how tertiary institutions in South Africa concepttualise mechatronic engineering and equip students with the necessitous skills and qualifications required; ultimately ensuring that graduates are equipped with the specialised skills required to operate as a mechatronic engineer. The scholarship provides evidence that the field of mechatronics has been subjected to haphazard expansion globally and that courses for mechatronics contrast across the world. Japan incorporated mechatronic engineering into its curricula in the 1970s, compared to South Africa which began this process only 30 years ago, indicating evidence of the contrast. While the field continues to expand and scale across disciplines, it is becoming increasingly necessary for developing economies like South Africa to prioritise mechatronics processes for professionals to remain competitive within the global manufacturing indus- 
try. Relatedly, a study on the development of mechatronic engineering courses has not been undertaken in South Africa. This predicament gives impetus to a study of this nature. Theoretically, this research contemplates how education counters to the new constructs in mechatronics. Based on 50 in-depth interviews in three provinces, it considers the nature of mechatronic engineering and its accreditation status from the Engineering Council of South Africa, focusing on how six tertiary institutions across South Africa have designed their curricula to meet the industry demand for mechatronic engineers. These locations included the Western Cape (3), Eastern Cape (1) and KwaZulu-Natal (2). Discourses among students and academics, which affect the perception of mechatronic engineers within the broader engineering fraternity, are interrogated. Based on this research, the paper illustrates that constructing a qualification for an emerging qualification is an arduous process, often founded on the perceptions of the institution, its previous knowledge and directed by industry demands. By utilising the discipline of mechatronic engineering, the paper aims to scrutinise this practice and identify progress and challenges faced by those with first-hand experience of these mechatronic courses.

Keywords: Mechatronic, qualifications, fledgling profession, ECSA, South Africa

\section{Introduction}

In 2003, mechatronic engineering was voted amid the top ten technologies that would revolutionise society; acknowledged as an emergent area of engineering that will 'likely alter the fundamental nature of engineering' (Giurgiutiu Bayoumi \& Nall 2002: 169). Notwithstanding, authors such as Maties, Vlasin and Tamas (2019) assent that mechatronics is a 'major need' in a range of economies. These edicts are based on the integrative approach which mechatronics offers, in comparison to more traditional, rigid parameters covering mechanical and electronic engineering. The scrimmage between authors on its exact definition can be traced back to 1996, with some appealing for a concise definition of the field, while others suggest a more inclusive definition as the uses, processes, and products of mechatronic engineering become known. It is within this context that consideration is given to Wolff's (2013) definition, which considers the South African context: 
Mechatronics Engineering is the concurrent design, manufacture, integration, and maintenance of controlled dynamic electro-mechanical systems (Wolffe 2013: 85).

BizCommunity (2019) develops this further, emphasising the need for South Africa's economy to prioritise the discipline and embrace this as the way forward for the emergent economy, articulating thus:

Mechatronics is a combination of mechanics and electronics, comprising a multi-disciplinary engineering field that is a key player in industry 4.0, the current trend of automation and data exchange in manufacturing technologies. It encompasses cyber-physical systems, the Internet of things, cloud computing, and cognitive computing (BizCommunity 2019: 1).

Evidently, as an emerging profession that is deemed an important role player in industry 4.0 (Maties et al. 2019), tertiary institutions have had to conceive qualifications and turn out mechatronic engineers to respond to this evolution in engineering. While researchers (Hsu1999; Habib 2006; Kumile 2008) have not agreed on a single definition and the expanding scope of the profession, the demand for qualified mechatronic engineers remains a priority. This proffers the question: how do tertiary institutions conceive qualifications for a new profession or discipline that is still emerging and expanding, further posing the question: How do tertiary institutions in South Africa make sense of and make room for mechatronic qualifications within their curricula?

\section{Theoretical Framework}

The study is premised from the constructivist perspective, which is one of the most prominent approaches to knowledge construction. It is especially apt when investigating how curricula are constructed and how this is shaped by social factors. Both Piaget and Vygotsky, although often viewed as opposing forces in the constructivism debate, agree that social factors as well as individual agency influence how knowledge is formed. Taking this further, Smith (2000) carries this into higher education, underscoring the fact that the construction of knowledge is contextual and, furthermore, that to view a curriculum based on a syllabus alone is limiting. Rather, the construction of 
knowledge via a curriculum is process-based, contingent on the product or outcome of knowledge and praxis (2000). In this way, the curriculum not only transmits knowledge of theory, but also incorporates aspects of practical problem solving that stimulates critical thinking and teamwork. Thus, as Jones and Brader-Araje (2002) show, the learner is active in the construction of their knowledge, especially if they are able to evaluate the course and collaborate with others. Of course, as a fledgling discipline, the introduction of the new curricula must also be based on a 'diagnosis of need,' as Bobbit (cited in Smith 2000) argues, which considers economic needs (for example the demand for mechatronic graduates), an institution's understanding of the discipline, and how the curriculum should be constructed in order to transmit knowledge and skills to produce the best outcome (skills).

\section{Mechatronics Education: A Historical Global Perspective}

The idea of mechatronics was initiated approximately half a century ago in Japan as a result of the mounting usage of central processing units (CPUs) for the regulation of machine-driven activities and procedures (Bradley et al. 2015). As the measure of mechatronic progression, literature from Japan is prioritised, with it being the first to acknowledge the innovation and value mechatronics engineering offered (Acar 1997; Schodt 1988; Seamus, Alan \& Shane 2018). Japan forged ahead, taking the lead on the information superhighway globally. Without delving too deeply into this concept, it is worth mentioning that culture plays an integral role in the acquiescence and integration of technology and how perceptions around technology are constructed. Japan, as global leaders, were the first to usher in mechatronic engineering qualifications in the 1970s at both an undergraduate and postgraduate level. Preferring a transdisciplinary approach of mechatronics, Acar (1997) notes that four-year undergraduate degrees and postgraduate qualifications have been adopted by the Japanese. The commitment by university departments at Toyohashi University to the discipline of mechatronics engineering has been ostensible and consistent since 1983. Belgium followed closely in its integration of tertiary mechatronics qualifications. Conversely, Buur (1990) documents that the curricula, inclusive of flexible strategies and design processes required by the fast-paced mechatronics work environments, seem to have been mastered by Japanese institutions in contrast to their rigid European equivalents. 
Even with the technological advancements and success yielded by Japan, the USA has led the way with its mechatronics innovation, which has contributed to over one-third of its economic growth, having delivered extensively to the development of computer technology (Venuvinod \& Reddy 2002). According to Venuvinod and Reddy (2002: 2), productivity and quality are key in the competitive strategy dynamic required by mechatronic engineers. The moment the excellence of a product increases, so too does competitiveness. Successively the convergence of technology, computerisation, and global communication owing to the Internet, as well as opportunities for innovation are amplified. Industrial progress and competitive advantage have consequently increased exponentially.

The competitive advantage can, in part, be attributed to the rapid success of information technology in Silicon Valley in California (USA). Much of this can be accredited to developments in mechatronic engineering, which offers innovative competitive solutions to production leading to economic growth. By 1996, mechatronics engineering scholars in the USA began documenting the impact and intricacies of this field in the first refereed journal. The academic journal was submitted to the IEEE/ASME Transactions on Mechatronics (Allen 2006). During the same period, the University of Washington refurbished its engineering department to consist of a course explicitly designed for mechatronic engineering (Giurgiutiu et al. 2002). By 2002, 13 tertiary institutions began offering postgraduate courses in the discipline of mechatronic engineering. However, in the USA only one undergraduate degree was accredited by ABET (Accreditation Board for Engineering and Technology) (Allen 2006). Despite the number of courses available in relation to the rest of the world, these curricula fall behind in terms of availability and accreditation.

Hong Kong was the first to offer an unexpurgated mechatronics programme in the Asian Pacific Region, offering mechatronics at the City University of Hong Kong in 1989 (Venuvinod et al. 1993). Analogously, Monash University in Australia (Ibrahim 2002) and the University of Wollongong aimed to create contemporary projects for their mechatronic engineering students. Cook, Naghdy and De Boer (2001) note that the increase in mechatronic courses internationally reflect a response to changing requirements of cutting-edge industry demands for interdisciplinary skills, generalist knowledge, and communication in teams. Governments around the world have accentuated their commitment and increased financial 
contributions toward the emergence of mechatronic specialisations, due to demands of the global economy. Canada invested $\$ 44.5$ million in technological projects, a number of which are based on mechatronics (Innovation.CA 2012). Global players have acknowledged the need for mechatronic specialists to guarantee a 'prosperous economy' that contributes to an increase in the quality of professions in the science and technology field. In the same way, $\$ 85$ million was invested by the Province of Trento in Italy where Italian trade unions at the Bonfiglio Mechatronics Research SpA helped to advance the discipline and establish the profession. The Bonfiglio Mechatronics Research Spa, inaugurated in July 2013, aimed to increase production activities, education and work in association with the University of Trento, to provide mechatronic tertiary education qualifications (Trentino 2012). The Italian government positions this as a refocus towards 'fiscal strength', affirming to engender a positive socio-economic outcome for the region. Universities in Switzerland and Slovenia have likewise fortified curriculum development and infrastructure to prioritise mechatronic qualifications, notwithstanding that it is the third-fastest-growing economic sector in Europe (Pipan \& Blažič 2009: 7).

Based on the increased dependency for mechatronic engineers skills; Jordan pioneered the facilitation of training qualifications and precipitous government investment, and was subsequently followed by developing countries. While mechatronics has been amalgamated into middle-eastern university qualifications in Egypt, Iraq and Syria, Jordan's Philadelphia University has, since 2000, emerged in the Middle East as the forerunner in education, offering a structured mechatronics degree. By 2002, mechatronic engineering was established as an independent department (Tutunji et al. 2007: 65-67). These authors note that the number of students quadrupled between 2000/2001 to 2005/2006, illustrating the spike in appeal for mechatronic engineering as a promising career path for young engineers (OECD 2015: 115). To entice students into mechatronics and retain this expertise, the Princess Sumaya University of Technology in Jordan aimed to create its first master's programme in mechatronics. Jordanian universities construct their curriculum on existing mechatronic programmes from leading universities across the industrialised world (Tutunji et al. 2007).

The emergence of mechatronics witnesses the new profession developing indiscriminately across the globe, and it is evident that the construction of mechatronics curricula has been based on the construction of knowledge, 
demands of the economy, and cultural perceptions around techno-logy. However haphazard, these trends are anticipated, and expound a compel-ling case for how a profession such as this will become instituted.

To respond to the needs of the global economy, voluminous mechatronic engineering programmes have been structured to adapt to the evolving nature of the market. However, students still perceive engineering curricula as outdated, traditional, long-winded, and above all complex. This is partly due to the shortcomings of tertiary institutions and academics who, Becker (2010) and Fackler (2008) point out, believe that engineering students deserve an exceptionally challenging curriculum. Similarly, scores of debates abound surrounding the length of an engineering degree, with some tertiary institutions maintaining five years for a student to be well equipped for the labour market. Students are often discouraged by this protracted and expensive commitment. With the emergence of mechatronic engineering however, there have been efforts to comply with technological advancements and maintain a rationalised curriculum. While this is laudable, there are considerable discrepancies in the courses lectured on and the length of mechatronics education around the globe. At Monash University, mechatronics education encompasses a four-year degree which is largely objective-driven. Its key objective is:

To equip the course participants with the necessary knowledge and skills, and prepare them to manage holistically and creatively, in a professional manner, the multidisciplinary tasks which include design, development and service of modern-day machines and devices (Ibrahim 2002: 1328).

Similarly, universities in the USA prefer to offer courses within a mechanical or engineering degree, which focuses on mechatronics. The student will be enrolled for a mechanical engineering degree, then move to the electronic engineering department for specific courses and subsequently advance to mechatronics. At the University of Canterbury (Chen et al. 2008) students receive mechatronic-specific subjects from the first year, as it is integrated into the curriculum. The programme lasts four years and has an increased focus on laboratory work and project designs. In Switzerland, a significant component of the mechatronics course is constructed on web learning and teamwork, which culminates in a robotics competition (Piguet, 
Mondada \& Siegwart 2001). This is a zenith of the work executed in the preceding years in conjunction with their proficiencies in problem-solving.

While it is commendable that several countries offer mechatronics at university, it is disquieting that there are discrepancies in terms of the length and content of the courses. Hsu (1999), Grimheden and Hansen (2005) and Habib (2006) suggest that the existence of a global discrepancy in what it means to be a mechatronics engineer is owing to a skewed technological progression. An added trepidation is the accreditation of qualifications. To sustain international standards of engineering education, various countries have become signatories of the Washington Accord. This is an agreement established in 1989, according to which, all councils representing each country must comply. This Accord, along with the Sydney and Dublin Accords (which handle technical diplomas and other jurisdictions), is responsible for accrediting the tertiary-level engineering qualifications in the countries that are signatories (Alliance 2013).

The Accord serves to maintain an international level and standard of engineering education to ensure that qualified engineers operate at a professional level. Conversely, Allen (2006) raises concerns that while numerous mechatronics qualifications are available in the USA, there is only one undergraduate degree that is recognised by ABET and the Washington Accord. The United Arab Emirates is not a signatory of the Washington Accord, despite their high education quality rating globally. Similarly, a oneyear ADAM qualification is not officially accredited; yet it is sponsored by governments in India and receives large capital investment from Mercedes Benz. Mercedes Benz has collaborated with the Indian government and tertiary institutions to provide mechatronics education to engineering graduates in Pune and Aurangabad in India (Bapat 2012). Owing to a lack of local automobile engineers and unemployment, a one-year Advanced Diploma in Automotive Mechatronics (ADAM) enables students to easily secure a job in the auto industry, work on foreign-manufactured cars, and start off their own businesses. To be eligible to secure one of the 40 seats available per year, prospective students are required to have an engineering degree and to pay 80000 Rupee in registration fees. The course, which comprises four modules, introduces students to German technology and related problem-solving skills. Due to the resounding success of this course in Pune and Aurangabad, Mercedes Benz is in the process of making the course available in a third location in India. 
Hence, training and quality of education may be compromised due to sub-par programmes that are not governed by collective global standards. Of significant importance, the level and content of education may differ considerably, leaving engineering graduates around the world with varying ideas on what is included in mechatronics. This leads to questions challenging what it means to be a mechatronics engineer in various geographical locations.

At present, scrutiny of existing literature on mechatronics curricula indicates that tertiary education institutions still grapple with this aspect of homogeneity in the mechatronics engineering curricula. In first-world countries, mechatronic engineering is utilised to facilitate driverless cars and airborne surveillance of sensitive areas (Marzano, Martinous \& Usca 2019), as well as integrating cloud computing into the discipline (Russell 2016), while in developing economies the discipline is mainly used in manufacturing contexts. Marzano et al. (2019: 214) contend that the development of curricula is not homogeneous across the globe. This is compounded by the fact that as mechatronics expands in scope and depth, the complexity increases, smart sensors become smaller, and processes become increasingly wireless (Eichinger, Hofig \& Richter 2017). This results in haphazard development of curricula and ultimately creates discrepancies between mechatronic engineers and graduates, if not for a broader gap between countries on the notorious information superhighway.

In addressing this concern, Eichinger et al. (2017), Maties et al. (2019), and Marzano et al. (2019) propose a systems-thinking approach based primarily on project-based practical problem-solving skills, rather than strict traditional pedagogies of engineering education. The NewMetro project, funded by the European Union, proposes a practical-based educational curriculum for mechatronic engineering, which further compounds the gap between countries. Simpson, Bradley and Hehenberger (2018) concur with the approach, contending that students need to learn how to innovate and should be allowed to take risks and experience failures if they are expected to develop themselves as mechatronic engineers in a world of intelligent integration. Hadgraft et al. (2019) elucidate that academic staff are aligned to traditional pedagogies and students are accustomed to an exam-driven curriculum. Based on a case study in Sydney, they proposed a studio model for developing their mechatronic engineering curriculum. This studio model includes four distinct aspects; firstly, the consulting of industry partners on hard and soft skills required of mechatronic engineering graduates; secondly, consulting the 
students on their evaluation of previously attended courses is critical; the third component includes consulting the staff on their competencies and suggestions; with finally, designing a sample curriculum based on real projects with industry partners and combining this with seminal theory.

In this way, various levels of complexity are addressed in the practical project within the studio space, while teaching occurs around seminal work in the academic space. While the studio model presents the ideal framework for a dynamic mechatronic engineering curriculum, it may indeed be problematic in developing economies where industry partners are new to the term, access to the equipment may be erratic, and technology is expensive to maintain and upgrade.

A developing economy like South Africa has been slow in facilitating education for mechatronics engineers who are key role-players in innovation in countries around the world. For automotive companies in particular, Kumile (2008: 2) emphasises the need for mechatronics, not only for the upscaling of skills but as a commercial strategy to gain access to new markets that demand innovation. Thus, the need for mechatronics engineers cannot be understated. However, training support in South Africa gives the impression that it unstructured. Where EU regions such as Germany, Estonia and Turkey are known for their facilities that train mechatronic engineers (Grimheden \& Hanson 2005; Maties et al. 2019), the literature does not point to any methods of training in South Africa, apart from hinting at its presence in the robotic sector (Science Scope 2007). More recently, it was established that the Stellenbosch University offers a mechatronics engineering course (University of Stellenbosch Online 2013), and the Nelson Mandela Metropolitan University recently began offering a BEng degree specifically focused on mechatronics. These are accredited by the Engineering Council of South Africa as outlined in the university syllabi. Festo, a Durban-based engineering company offers outsourced training to companies that require mechatronic engineers. In establishing mechatronics as a new profession, these concerns around training and tertiary education are key influences of its emergence.

\section{Methodology}

Due to the profession of mechatronics being relatively new, only three South African universities around the country offer undergraduate courses in mechatronics engineering. The research was conducted across South Africa, 
with a focus on four provinces of nine provinces, namely the Western Cape, Gauteng, Eastern Cape, and KwaZulu-Natal, as indicated in Figure 1 in colour. The universities in the Western Cape, Eastern Cape and KZN will be referred to as $\mathrm{WC} 1$ and $\mathrm{WC} 2, \mathrm{EC} 1$ and $\mathrm{KZN} 1$, respectively.

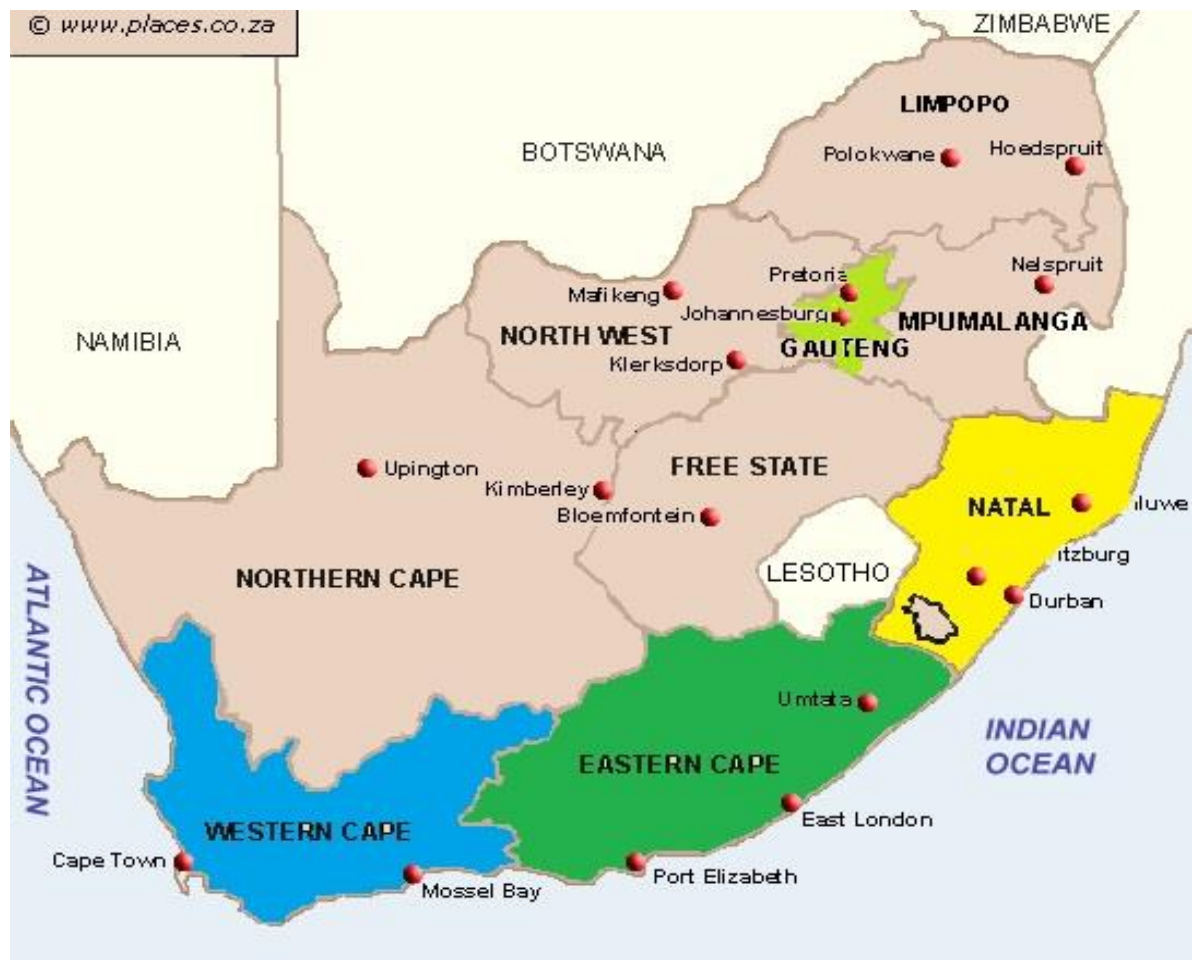

Figure 1. Research site indicating the Western Cape, Eastern Cape, Gauteng, KwaZulu-Natal as areas of investigation

Table 1 shows that only three universities offer a Bachelor of Engineering degree in mechatronics. However, there is a focus on mechatronics at KZN1, which offers a postgraduate mechatronics research master's'degreefor their mechanical engineering students. 
Quraisha Dawood \& Mariam Seedat-Khan

Table 1: Graduates in South Africa 2008-2012

(Source: Personal communication with respondents)

\begin{tabular}{|l|c|c|c|c|c|c|}
\hline Province & University & $\mathbf{2 0 0 8}$ & $\mathbf{2 0 0 9}$ & $\mathbf{2 0 1 0}$ & $\mathbf{2 0 1 1}$ & $\mathbf{2 0 1 2}$ \\
\hline \multirow{2}{*}{ Western Cape } & WC1 & 34 & 38 & 26 & 36 & 46 \\
\cline { 2 - 7 } & WC2 & 29 & 51 & 36 & 42 & 40 \\
\hline Eastern Cape & EC1 & 7 & 14 & 17 & 16 & 23 \\
\hline Total & & 70 & 103 & 79 & 94 & 109 \\
\hline Total & & \multicolumn{5}{|c|}{$\mathbf{4 5 5}$} \\
\hline
\end{tabular}

The first focus is on the Western Cape, as the province produces the greatest number of graduates due to two universities (see Table 1) offering mechatronic engineering degrees. Three mechatronic engineering firms are situated in the region, which mainly supply the automobile or smart device markets. In addition, the researchers focus on Gauteng, as mechatronics is used in weapons manufacturing and mining. The area also has several companies that provide mechatronic components to manufacturers. The Eastern Cape, as an area in which large automobile industries are located, also provided much insight into this study. EC1 university offers the only mechatronics engineering degree in the region and the head of the MerSETA ${ }^{1}$ for EC1 is housed there. The university also has partnerships with mechatronic-centred international engineering companies. Various companies here use mechatronics to automate assembly lines.

Finally, the research site included KwaZulu-Natal. Here too companies align themselves with the automobile industry in providing mechatronic equipment that tests quality or runs assembly lines in the food and beverage sector. However, KZN1, which offers a postgraduate course in mechatronics, finds a use for mechatronics in the biomedical industry in relation to the creation and development of prosthetics. It should be noted that while Table 1 reveals 455 mechatronic engineers in South Africa, some may have located employment abroad or they may have been immersed into contiguous engineering disciplines (at least two of the study's sample work in the UK). To provide a complete picture of the development of mechatronics in South Africa, this study also considers samples from national organisations that sup-

1 Manufacturing, Engineering and Related Services Sector Education and Training Authority. 
port technological innovation by funding research, patenting designs, and registering engineers. These include the Technological Innovation Agency (TIA), the Engineering Council of South Africa (ECSA), the Council for Scientific and Industrial Research (CSIR), engineering training academies, academics, employers and those in adjacent occupations. Due to the dispersed nature of mechatronics education, various industries that use it across South Africa, and the difficulty in locating participants, a national approach was adopted for exploring how a new profession emerges in South Africa, specifically focusing on mechatronic engineering. To understand the rationale behind highly skilled workers emigrating, two mechatronic engineers who found work in the United Kingdom were interviewed.

\section{Sampling and Data Collection}

The study employed a qualitative method of inquiry. In-depth interviews and documentary data were used to obtain a holistic insight into the intricacies of identities in an emerging profession. The method recognises and emphasises the social context, emotions, and life stories of its subjects, focusing on soft data and life stories in their natural setting (Gray et al. 2007) to gauge rich data. Over a period of ten months, a total of 50 participants were interviewed. These included mechatronic engineers, mechatronics engineering students, academics who lectured mechatronic graduates, employers of mechatronic engineeers, and a few working in adjacent professions. Key informants working in organisations such as the Technological Innovation Agency, MerSETA (the Manufacturing, Engineering and Related Services sector education authority) and the Engineering Council of South Africa (ECSA) were also interviewed.

Due to the dearth of mechatronic engineers in South Africa and a lack of a list of mechatronic engineers, snowball sampling was used to access participants from around the country.

The one-on-one, in-depth interviews lasted between 40 to 60 minutes at the workplaces of the participants, who were ensured confidentiality through signing informed consent forms. These interviews were transcribed and translated into themes for data analysis. The researcher was allowed an hour to observe the workplaces where mechatronic engineers worked and interacted with those in adjacent professions. Documentary data such as syllabi from the universities and universities of technology involved, social media posts, job vacancies in the news articles or online (CareerJet, PNet, JobisJob), and rules 
and regulations or brochures were also collected between 2012 and 2015 . These were analysed using NVivo and word frequencies. This allowed for a multi-faceted or bricolage understanding of the data.

\section{Findings}

All participants interviewed for this study considered tertiary institutions as the main facilitator for the emergence of a new profession. For them, institutions which confer the qualification of 'mechatronics engineer' were the most significant factor in the establishment of mechatronics as a legitimate profession.

Based on interviews and the curricula of tertiary institutions offering mechatronics courses, the study can offer a visual insight into the core subjects in these qualifications, duration of the courses and qualifications students may achieve after completion, as depicted in Table 2. Table 2 takes into account data from four South African universities in which students may pursue a qualification in mechatronic engineering. Also included in Table 2 are two universities of technology (formerly Technikons) which offer mechatronics engineering courses, referred to as KZNTech (located in Durban) and WCTech (located in Cape Town).

The purpose of such interrogation is not to investigate the subject of the courses themselves, but rather to assess how these institutions make sense of, and consequently shape, the rise of mechatronics in South Africa. This will include whether mechatronics is approached from a mechanical or electrical engineeering point of view (i.e. which elements of mechatronics are emphasised), what type of careers these courses equip graduates for, as well as how universities and former Technikons compare in relation to employers' expectations from mechatronic graduates. Firstly, as demonstrated in Table 1, mechatronics courses are relatively new - the first qualified mechatronic engineers graduated from WC1 in 2005. This mirrors a demand from industry for a systems-integrated, innovative approach to engineering. As Professor Thomas Bezuidenhout ${ }^{2}$ reveals, since then applications for mechatronic engineering have increased; this was corroborated by visits to tertiary institutions which confirmed that all mechatronic labs were filled.

${ }^{2}$ Interview, Prof Thomas Bezuidenhout, 16/09/2013, Cape Town. 
The Emerging Profession of Mechatronic Engineering

\begin{tabular}{|c|c|c|c|}
\hline & 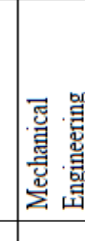 & 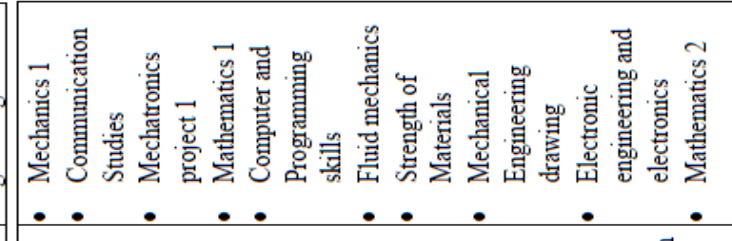 & 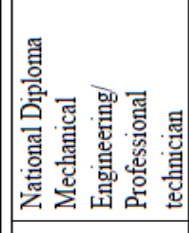 \\
\hline & 吾哭 & 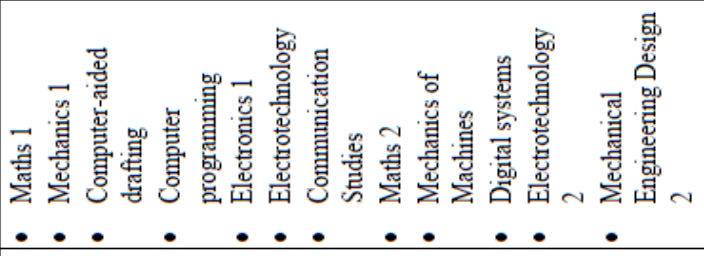 & 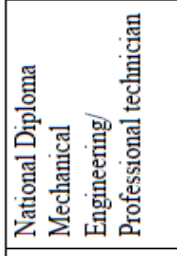 \\
\hline & 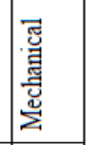 & 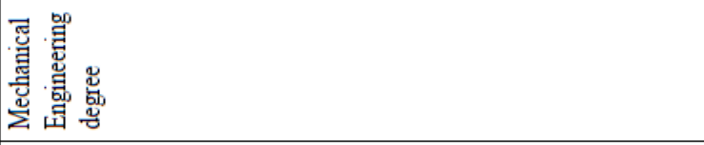 & 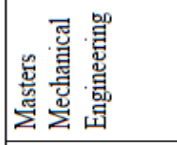 \\
\hline & 苞, & 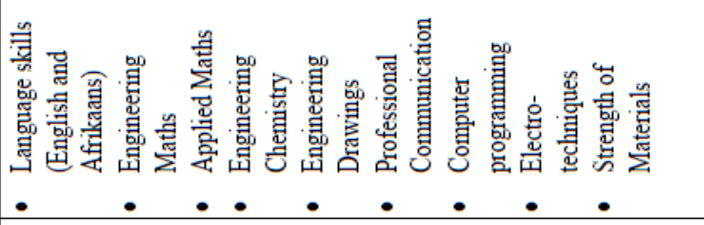 & 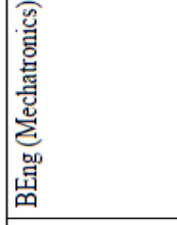 \\
\hline 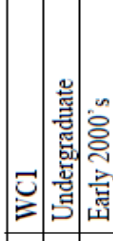 & 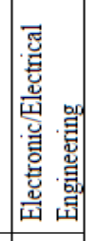 & 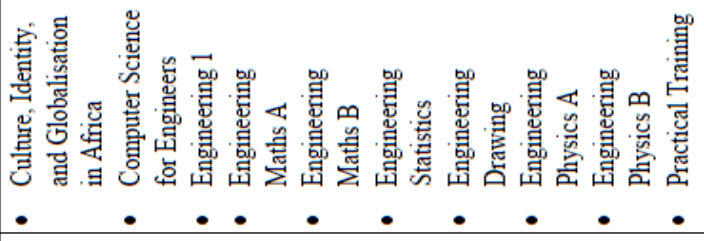 & 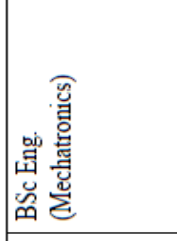 \\
\hline 窇| & $\mid$ & 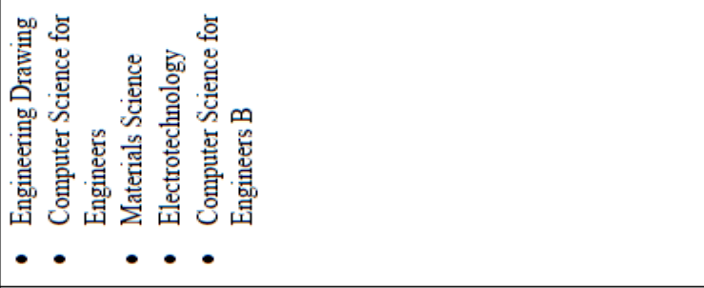 & 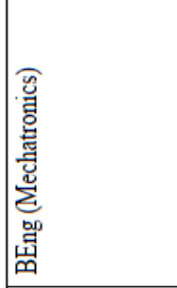 \\
\hline 瑴 & 童 & 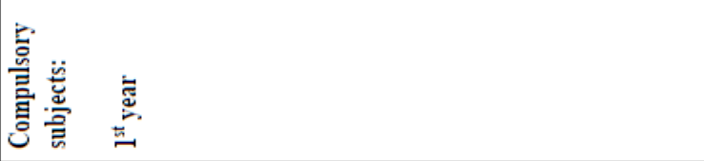 & 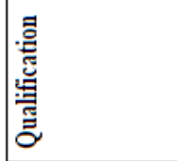 \\
\hline
\end{tabular}




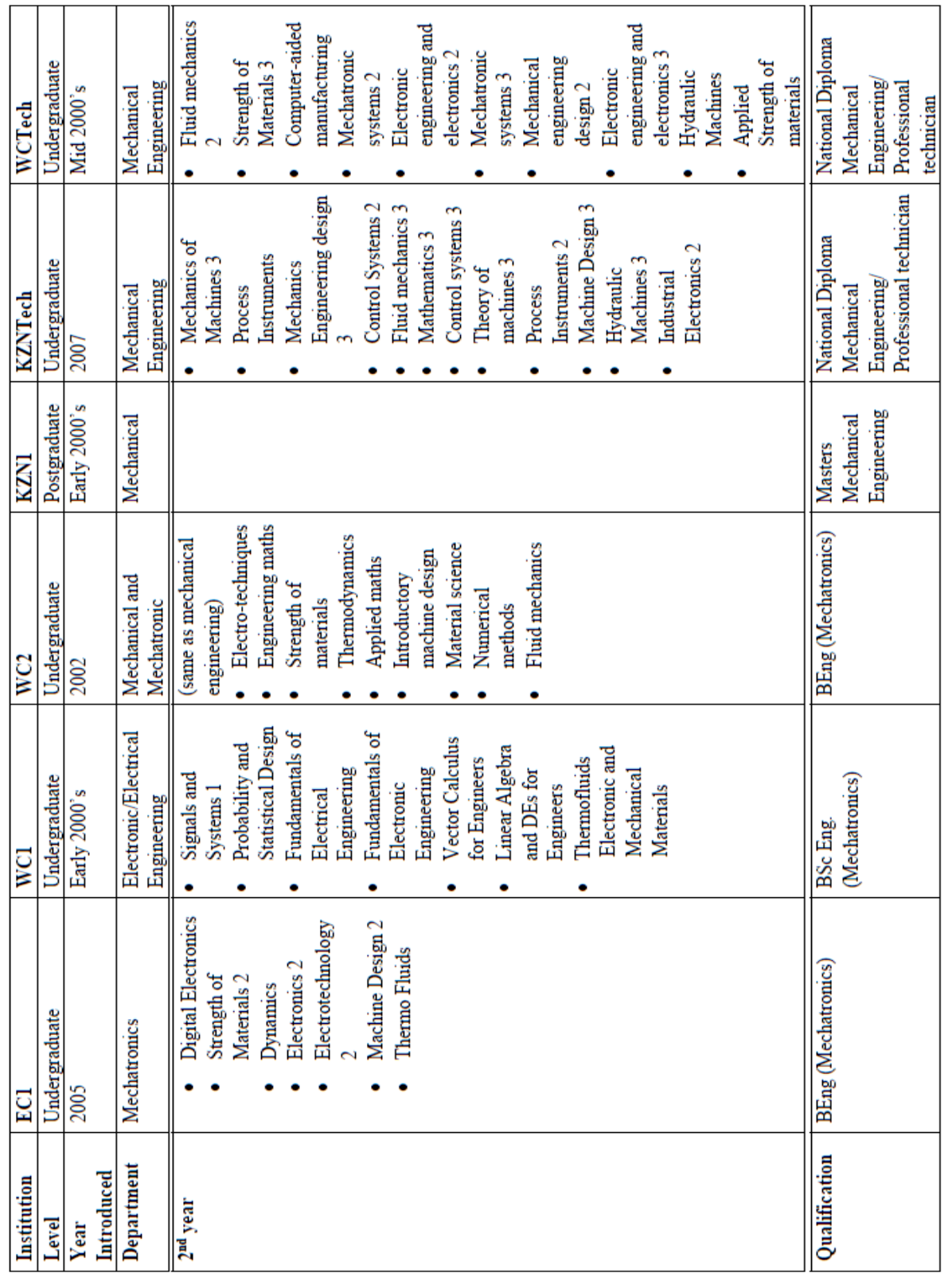


The Emerging Profession of Mechatronic Engineering

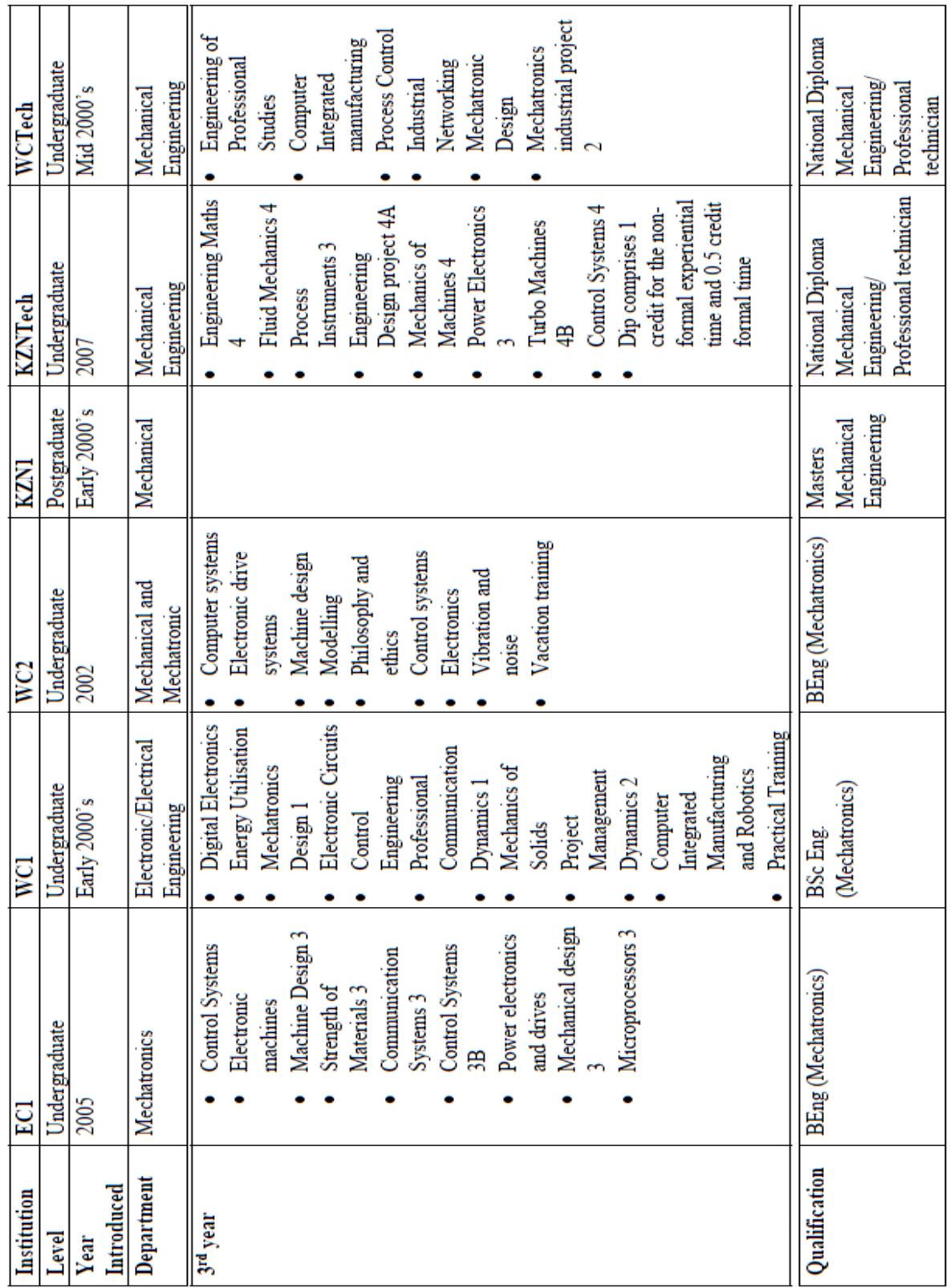




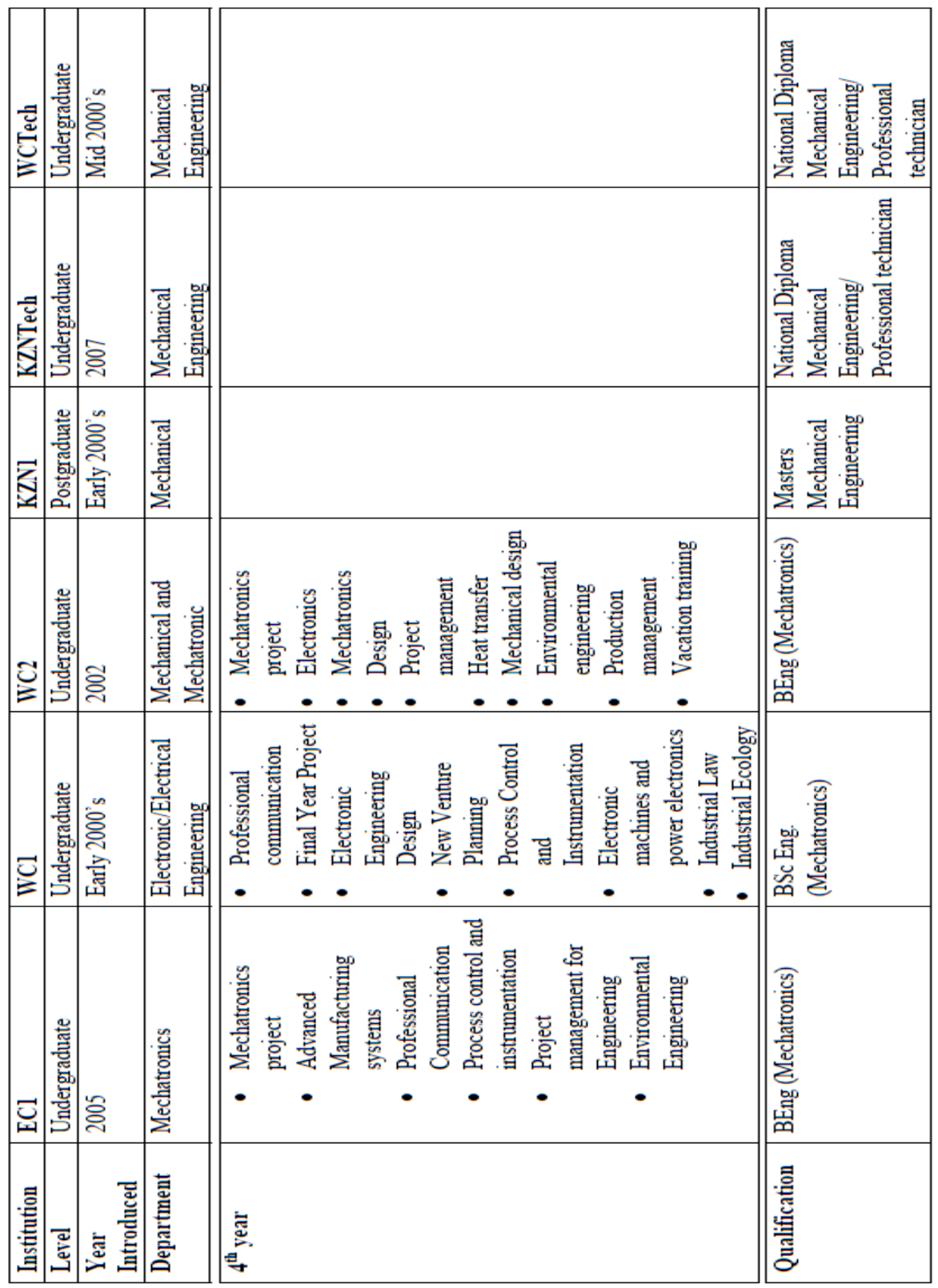


One of the key observations highlighted in Table 2 is that most tertiary institutions make sense of mechatronics via the traditional professions of mechanical and electronic engineering. Thus, institutions seem to favour one and then combine elements of both to create a mechatronics qualification. Tertiary institutions interviewed for this study view mechatronics as a stream of mechanical engineering, with the exception of EC1, which offers an independent mechatronics course. However, WC2 is highlighted for aligning mechatronics with electronic engineering. According to academics at the university, there is an electro-mechanical engineering degree within mechanical engineeering, which focuses on heavy current engineering and less on computer control. Despite some misperceiving this with mechatronics, it must be noted that mechatronics emphasises control systems, robotics and light currents as well as project management. In this way, WC1 constructed the mechatronics curriculum from an electronic engineering point of view. Unfortunately, this debate surrounding whether mechatronics leans more towards mechanical engineering or electronic engineering is ongoing, with each university claiming to have the superlative approach. For example, a senior KZN1 academic, Dr Clive Gordon ${ }^{3}$ stated,

Even though we are labelled as mechanical, in truth we are mechatronics. You don't get mechanical systems operating on their own anymore, so we integrate electronics into our degrees. Mechatronics is systems integration.

Furthermore, he mentioned that mechatronics should always lean towards mechanical engineering because students learn that when moving mass, they need to consider inertia and that takes time.

On the other hand, with electronics, students expect an instant result, like on the computer, and they are not sensitive to how mass moves to produce the desired effect. He added that the reason they had not changed the name of the degree from mechanical to mechatronics was that he knew what was best for his students and that they would be more employable with a degree that was more familiar to the industry. On the other hand, a senior professor ${ }^{4}$ at EC1 claimed:

${ }^{3}$ Interview, Dr. Clive Gordon, 07/11/2013, Durban.

${ }^{4}$ Interview, Prof. Johan van Staden, 24/02/2014, Port Elizabeth. 
We are pure mechatronics. WC2 and WC1 were born from mechanical and electronic, but we were born from nothing ... which means we could set up our degree how we saw fit. I would say the (WC2) degree that leans towards mechanical is closer to mechatronics, while (WC1) is still quite electronic (Prof Johan van Staden).

To combat this dilemma, an academic from Gauteng, Dr Kyle Jackson $^{5}$. observed that universities abroad have implemented two mechatronic engineering degrees - one in electronic engineering and another in mechanical engineering. 'Nobody knows where it fits - its somewhere in the middle', he said.

In most tertiary institutions all engineering students (civil, chemical, mechanical) are required to complete similar courses in the first year to have a base or grounding in foundation subjects (refer to Table 2). At KZN1 (which does not offer undergraduate mechatronics engineering courses) a student must graduate with a mechanical engineering degree, and then join the mechatronics research group at Master's level to complete a mechatronic project. In equipping students for a career in mechatronics engineering, there are some discrepancies between courses and concerns around practical training. In the first year, as Table 2 indicates, courses are similar across the board. However, one anomaly - which is that EC1 does not require mathematics as a compulsory subject. Amina Mohamed, ${ }^{6}$ a third-year student, related that in the first year the mathematics competency level of students in her class varied, and she often felt intimidated by foreign students who could understand complex problems. Thus, a course to bring all students to the same level was lacking in this respect.

As shown in Table 2, WC1 and WC2 introduce their students to a spectrum of fields in their first year, with WC2 leaning more towards mechanical engineering subjects. The former Technikon, WCTech, must be commended for the introduction to a mechatronics project in the first year, which other tertiary institutions seem to lack. Comparing courses in the second year, EC1 lacks mathematics. Maths provides a basis for understanding how and why concepts work together and this may be a fundamental flaw in the curriculum. Similarly, WC2 lacks a course detailing the fundamentals for electronic and electrical engineering in its third year. However, they are to be

${ }^{5}$ Interview, Dr Kyle Jackson, 10/10/2013, Johannesburg.
${ }^{6}$ Interview, Amina Mohamed, 24/02/2014, Port Elizabeth. 
extolled for their machine design course. WCTech is highlighted once again for its computer-aided manufacturing course. Looking at Table 2, one respondent ${ }^{7}$ explained that this course emphasises the industry's needs and future demands, adding good practical experience to a student's learning environment.

Overall, mechatronics seems to branch out on its own in the third year. In WC2 in particular, mechatronic engineering students separate from mechanical engineering students and are geared towards a more integrative approach to engineering with subjects that focus on electronics and control systems as well as vacation training. WC1 emphasises a project management approach to engineering and with the CIM and Robotics course, offers students invaluable insight into smart machines. This course, as a participant ${ }^{8}$ mentioned, should be included at all tertiary institutions that offer mechatronics; however, such a course, considering the equipment used, would be quite expensive and require funding. In the fourth year, all the universities require of students to embark on a final-year project. However, students ${ }^{9}$ interviewed critiqued EC1 for having no 'build-up' to the project. They had never done a robotics project before. By this stage, students viewed the project with dread, and the project management course came too late in the curriculum. Amina explains:

I'm already stressed about my final project. I've been stressed about it since first-year ... that's the only project of its kind I will do. I wish they would introduce it on a smaller scale in the second year. Somehow now the lecturers expect you to start building something from scratch and it must work. My friends who are doing that are so lost ... I feel the diploma students know so much more practical stuff than we do (Amina Mohamed).

In this way, the construction of knowledge lacks the input of the student, a key tenet of the constructivist approach. Project management finds itself in the same predicament at WC2. Overall, UCT offers a much more holistic approach in the final year by preparing students through the robotics

\footnotetext{
${ }^{7}$ Interview, Shahid Karim, 12/07/2013, Durban.

${ }^{8}$ Interview, Ethan Dyer, 20/09/2013, Durban.

${ }^{9}$ Interviews: Amina Mohamed and Ethan Dyer.
} 
course and practical training before the final project. None of the tertiary institutions place much emphasis on computer programming, as this skill was meant to be 'picked up' along the way. When comparing the universities, KZN1 and WC2 offer a very mechanical approach to mechatronics, while WC1 focuses more on electronics and robotics in a balanced approach to industry demands. EC1 in particular gears students to an extremely specific field in the industry - the automobile sector - and has an affiliation with Volkswagen. What this means is that graduates across South Africa are not necessarily going to approach mechatronics homogenously. A graduate from KZN1 or WC2, for example, will look towards finding a more mechanical solution to an engineering problem, while a graduate from $\mathrm{WC} 1$ may provide a robotic solution.

Employers ${ }^{10}$ of mechatronic graduates interviewed for this study, critiqued universities for not emphasising practical training (process-based learning) as much as the former Technikons did. As Table 2 indicates, diploma students are required to complete practical training and are granted credits for this, while vacation training is not credit bearing within the university framework. Furthermore, 'hands-on' projects are introduced in later years during university degrees, which may be too late in the course. Concerns abound among students, graduates, and employers surrounding the amount of practical experience afforded to students to prepare them for employment. This echoes the researchers' concerns that a curriculum needs to place more emphasis on practical problem solving and consultation with industry partners, rather than traditional, exam-based studies. In relation to the construction of knowledge, the study finds that there is indeed a lack of process-based learning and student-centred feedback as necessitated by the constructivist approach.

In principle, 'how' mechatronics is emerging (its meaning) is varied across the country. Drawing on the data in Table 2, it becomes evident that tertiary institutions are unsure of what comprises a mechatronics course - they are unsure of how to 'make sense' of it. This is one of the characteristics of an emerging profession. However, it is established that 'murkiness' is a significant factor in the emergence of this new profession, and the role that tertiary institutions play in the shape mechatronics takes as it develops. When focusing on tertiary institutions that confer qualifications for a new profession,

\footnotetext{
${ }^{10}$ Interviews, Hans Rossouw, 18/09/2013, Cape Town; Interview, Gert Durant, 24/02/2014, Port Elizabeth.
} 
it is important to bear in mind the regulatory body which accredits these qualifications, and how this body makes sense of mechatronics - where it fits and what criteria mechatronic qualifications adhere to.

\section{Regulatory Body (ECSA)}

Engineering Council of South Africa regulates, accredits and registers tertiarylevel engineering diplomas and degrees across the country. This council allows engineers and engineering disciplines to gain legitimacy through qualification and certain experiential criteria. For this reason, the study explores how the council makes sense of mechatronics; what outcomes it expects from graduates of such degrees; and, whether it supports the emergence of mechatronics through the professional registration of mechatronic engineers. As stipulated, tertiary institutions are obligated to adhere to ECSA criteria surrounding courses, practical training and learning outcomes in order to be legitimised. The ten learning outcomes outline by the ECSA website and adhered to by universities are depicted in Table 3.

Table 3: ECSA's Ten Learning Outcomes (Source: ECSA website).

\begin{tabular}{|l|l|l|}
\hline $\begin{array}{c}\text { Exit Level } \\
\text { Outcome }\end{array}$ & \multicolumn{1}{|c|}{$\begin{array}{c}\text { Capacity/Ability of } \\
\text { Student }\end{array}$} & \multicolumn{1}{c|}{ Learning Outcome } \\
\hline $\mathbf{1}$ & Problem Solving & $\begin{array}{l}\text { Demonstrate competence to } \\
\text { identify, assess, formulate, and } \\
\text { solve convergent } \text { and } \text { divergent } \\
\text { engineering problems creatively } \\
\text { and innovatively. }\end{array}$ \\
\hline $\mathbf{3}$ & $\begin{array}{l}\text { Application of Scientific } \\
\text { and Engineering } \\
\text { Knowledge }\end{array}$ & $\begin{array}{l}\text { Demonstrate competence to } \\
\text { apply knowledge of } \\
\text { mathematics, basic science, and } \\
\text { engineering sciences from first } \\
\text { principles to solve engineering } \\
\text { problems. }\end{array}$ \\
\hline $\mathbf{3}$ & Engineering Design & $\begin{array}{l}\text { Demonstrate competence to } \\
\text { perform creative, procedural } \\
\text { and non-procedural design and } \\
\text { synthesis of components, } \\
\text { systems, engineering works, } \\
\text { products or processes }\end{array}$ \\
\hline
\end{tabular}




\begin{tabular}{|c|c|c|}
\hline 4 & $\begin{array}{l}\text { Investigations, experiments } \\
\text { and data analysis }\end{array}$ & $\begin{array}{l}\text { Demonstrate competence to } \\
\text { design and conduct } \\
\text { investigations and experiments. }\end{array}$ \\
\hline 5 & $\begin{array}{l}\text { Engineering methods, } \\
\text { skills, and tools, including } \\
\text { Information Technology }\end{array}$ & $\begin{array}{l}\text { Demonstrate competence to use } \\
\text { appropriate engineering } \\
\text { methods, skills, and tools, } \\
\text { including those based on } \\
\text { information technology. }\end{array}$ \\
\hline 6 & $\begin{array}{l}\text { Professional and Technical } \\
\text { Communication }\end{array}$ & $\begin{array}{l}\text { Demonstrate competence to } \\
\text { communicate effectively, both } \\
\text { orally and in writing, with } \\
\text { engineering audiences and the } \\
\text { community at large. }\end{array}$ \\
\hline 7 & $\begin{array}{l}\text { Impact of engineering } \\
\text { activity }\end{array}$ & $\begin{array}{l}\text { Demonstrate a critical } \\
\text { awareness of the impact of } \\
\text { engineering activity on the } \\
\text { social, industrial, and physical } \\
\text { environment. }\end{array}$ \\
\hline 8 & $\begin{array}{l}\text { Individual, team and } \\
\text { multidisciplinary working }\end{array}$ & $\begin{array}{l}\text { Demonstrate competence to } \\
\text { work effectively as an } \\
\text { individual, in teams, and } \\
\text { multidisciplinary environments. }\end{array}$ \\
\hline 9 & $\begin{array}{l}\text { Independent learning } \\
\text { ability }\end{array}$ & $\begin{array}{l}\text { Demonstrate competence to } \\
\text { engage in independent learning } \\
\text { through well- } \\
\text { developed learning skills. }\end{array}$ \\
\hline 10 & $\begin{array}{l}\text { Engineering } \\
\text { professionalism }\end{array}$ & $\begin{array}{l}\text { Demonstrate a critical } \\
\text { awareness of the need to act } \\
\text { professionally and ethically and } \\
\text { to exercise judgment and take } \\
\text { responsibility within own limits } \\
\text { of competence. }\end{array}$ \\
\hline
\end{tabular}

An examination of the ECSA criteria demonstrates that all universities have complied with the learning outcomes, despite the observation from students and graduates that some courses leaned more towards mechanical or electronic engineering, and the concerns raised around practical training as part of the coursework. It is also interesting to note that ECSA values communication and professionalism (ethics and social responsibility) in its 
criteria for the engineering graduate. Ultimately, universities cannot deviate too much from these ECSA stipulations, or else they will face sanctions and lose accreditation. Thus, the student must decide which university he or she is better suited to. Universities cannot be fully liable for taking a stance on whether their courses lean more towards mechanical or electronic engineering. They will indeed produce graduates with varying understanding of mechatronics. However, it is commendable that there are several options open to students based on their individual capability.

ECSA, as a regulatory body, however, does not seem to understand or prioritise mechatronics. Upon investigation, both by viewing the ECSA website, as well as through in-depth interviews with mechatronic engineers, ${ }^{11}$ the study found that a mechatronic engineer cannot register with ECSA unless he or she selects electronic or mechanical engineering as his/her main domain. Mechatronics can only be selected as a specialisation or sub-group. A representative $^{12}$ from ECSA could not explain why this was the case; neither were they able to explain the fundamentals that would distinguish mechatronic engineering from other engineering specialties. The researcher was informed after numerous phone calls to the association that they were only an 'administrative' organisation and could not recommend anyone in the field of mechatronic engineering. This is unfortunate, as the council represents engineers on a national level. However, a senior professor at EC1 explained that this will soon change, as ECSA has granted mechatronics its trade test, independent of mechanical and electronic engineering. If ECSA were to grant mechatronics its independence by not constantly linking it to mechanical and electronic engineering and allowing candidates to register as mechatronics engineers, this would play a significant role in making sense of, and legitimising the emerging profession. However, this may take a few years to accomplish.

\section{Conclusion}

This paper has carefully and succinctly outlined how tertiary education institutions in South Africa have responded to formulating a strategy for their students to embark on a degree for a fledgling profession in the field of

${ }^{11}$ Interview, Tariq Parker, 19/09/2013, Cape Town; Niresh Rai, 26/03/2014, Pretoria, Adam Ferrera, 17/07/2013, Durban.

12 Telephonic interview, Rose Gwala, 15/01/2014, Johannesburg. 
mechatronic engineering. In adopting a constructivist approach to the construction of knowledge and the creation of curricula for a fledgling profession, it is clear that contextual demands of the economy, perceptions around technology and process-based learning are key in allowing a curriculum to be transmitted, adapted to the increasing scope of the discipline, and thereby produce graduates who problem-solve and think critically. The study asserts that engineering qualifications have been connected to a cultural mandate, while responding, albeit slowly, to industry demands, and have begun to make inroads with accredited associations that play an important role in the legitimisation of a fledgling profession. The qualifications framework and how tertiary educational institutions understand new professions have been detailed in relation to the universities explored in this study. While these tertiary institutions in South Africa conceptualise mechatronic engineering differently, each with strengths and limitations, have equipped their students with the necessitous skills and qualifications required in the field of mechatronic engineering, they could do more in terms of student evaluations and practical experience. Higher education institutions and ECSA hold the key to facilitating the advancement and consolidation of mechatronic engineering as a profession in the South African context, in doing so they will provide a model for developing countries and the global South.

\section{References}

Acar, M. 1997. Mechatronics Challenge for the Higher Education World. Components, Packaging, and Manufacturing Technology, Part C, IEEE Transactions on Mechatronics 20: 14 - 20.

https://doi.org/10.1109/3476.585140

Allen, R.G. 2006. Mechatronics Engineering: A Critical Need for this Interdisciplinary Approach to Engineering Education. Proceedings of the 2006 IJME-INTERTECH Conference on Synergistic Integration of Mechanical Engineering with Electronics, 2006. 20205085.

Alliance, I.E. 2013. Washington Accord: Signatories. Available at:

http://www.washingtonaccord.org/Washington-Accord/signatories.cfm

(Accessed 12 January 2014).

Bapat, N. 2012. Mechatronics Course Opens Doors. Available at:

http://www.sakaaltimes.com/20120702/5753687994879839221.htm

(Accessed on 08 March 2014). 
Becker, F.S. 2010. 'Why don't young people want to become engineers?' Rational Reasons for Disappointing Decisions. European Journal of Engineering Education 35: 349 - 366.

https://doi.org/10.1080/03043797.2010.489941

BizCommunity 2019. New Mechatronics Academy Targets the Automation Industry Skills Shortage.

https://www.bizcommunity.com/Article/196/499/188853.html

(Accessed 17 January 2020).

Bradley, D., D.W. Russell, I. Ferguson, J. Isaacs, A. MacLeod \& R. White 2015. The Internet of Things - The Future or the End of Mechatronics. Mechatronics 27: 57 - 74 .

https://doi.org/10.1016/j.mechatronics.2015.02.005

Buur, J. 1990. Mechatronics Design in Japan. Lyngby: Technical University of Denmark, Institute for Engineering Design.

Chen, X., P. Gaynor, R. King, J. Chase, P. Bones, P. Gough \& R. Duke 2008. A Project-based Mechatronics Program to Reinforce Mechatronic Thinking - A Restructuring Experience. The University of Canterbury. https://doi.org/10.3182/20080706-5-KR-1001.02639

Cook, C., F. Naghdy \& F. de Boer 2001. Postgraduate and Undergraduate Mechatronics Courses at the University of Wollongong. Proceedings. 2001 IEEE/ASME International Conference on Mechatronics, 2001. IEEE, 994 - 999.

ECSA: Requirements for Accreditation.

https://www.ecsa.co.za/register/SitePages/Professional\%20Engineer.asp $\underline{x}$

Eichinger, P., B. Hofig \& C. Richter, September 2017. Education 4.0 for Mechatronics - Agile and Smart. In 2017 International Conference on Research and Education in Mechatronics (REM), 1 - 7. IEEE.

https://doi.org/10.1109/REM.2017.8075231

Fackler, M. 2008. High-Tech Japan Running out of Engineers.

http://www.nytimes.com/2008/05/17/business/worldbusiness/17engineer s.html?pagewanted=all\& $\mathrm{r}=0$ (Accessed 15 January 2020.)

Giurgiutiu, V., A-M.E, \& G. Nall 2002. Mechatronics and Smart Structures:

Emerging Engineering Disciplines for the Third Millennium. Mechatronics 12: $169-181$.

https://doi.org/10.1016/S0957-4158(01)00057-5

Gray, P.S., J.B. Williamson, D.A. Karp \& J.R. Dalphin 2007. The Research 
Imagination: An Introduction into Qualitative and Quantitative Methods. USA: Cambridge. https://doi.org/10.1017/CBO9780511819391

Grimheden, M. \& M. Hanson 2005. Mechatronics - The Evolution of an Academic Discipline in Engineering Education. Mechatronics 15: 179 192. https://doi.org/10.1016/j.mechatronics.2004.07.010

Habib, M.K. 2006. Mechatronics Engineering: The Evolution, the Needs, the Challenges. IECON $20632^{\text {nd }}$ Annual Conference, 6-10 November. Paris, France. https://doi.org/10.1109/IECON.2006.347925

Hadgraft, R., B. Francis, T. Brown, R. Fitch \& B. Halkon 2019. Renewing Mechanical and Mechatronics Programs. AAEE2019.

Hsu, T. 1999. Development of an Undergraduate Curriculum in Mechatronics Systems Engineering. Journal of Engineering Education, April: 173 -

179. https://doi.org/10.1002/j.2168-9830.1999.tb00431.x

Ibrahim, M.Y. 2002. Development of a Mechatronics Course at Monash University, Australia. Industrial Technology. IEEE ICIT'02. IEEE

International Conference on Mechatronics, 2002. IEEE, 1327 - 1332.

Innovation.Ca. 2012. Government of Canada Announces Investments in Research Innovation.

http://www.innovation.ca/en/Media/News/GovernmentCanadaannounce sinvestmentsinresearchinnovation

Jones, M.G. \& L. Brader-Araje 2002. The Impact of Constructivism on Education: Language, Discourse, and Meaning. American Communication Journal 5: 3.

Kumile, C.M. 2008. Sensor Based Real-time Mechatronic Control of Computer Integrated Manufacturing. Unpublished $\mathrm{PhD}$, Faculty of Engineering, University of KwaZulu-Natal.

Marzano, G., A. Martinovs \& S. Usca 2019. Mechatronics Education: Needs and Challenges. In Proceedings of the $12^{\text {th }}$ International Scientific and Practical Conference II, 214: 217.

https://doi.org/10.17770/etr2019vol2.4199

Maties, V., I. Vlasin \& V. Tamas 2019. Transdisciplinary, Mechatronics and Organisational Learning. Transdisciplinary Journal of Engineering and Science 10: 158-168. https://doi.org/10.22545/2019/0126

OECD 2015. OECD Economic Surveys: China. Paris: OECD Publishing. https://books.google.co.za/books?id=OBl-

BwAAQBAJ\&lpg=PP1\&dq=bibliogroup $\% 3 \mathrm{~A} \% 22 \mathrm{OECD} \% 20$ Economic \%20Surveys\%3A\%20China\%22\&pg=PA2\#v=onepage \&q\&f=truehttps:/ 
/books.google.co.za/books?id=OBl-

BwAAQBAJ\&lpg=PP1\&dq=bibliogroup\%3A\%22OECD\%20Economic \%20Surveys \%3A\%20China\%22\&pg=PA2\#v=onepage\&q\&f=true

Piguet, Y., F. Mondada \& R. Siegwart 2001. New Environment for Learning

by Doing in Mechatronics Education. Workshop on Robotics Education and Training.

Pipan, M. \& B.J. Blažič 2009. Advanced eVocational Education of Mechatronic Professions. International Journal of Education and Infor-mation Technologies 1,3: 12 - 19.

Schodt, F.L. 1988. Inside the Robot Kingdom, USA: Kodansha Amer Inc. https://doi.org/10.1016/0278-6125(88)90048-9

Science Scope 2007. Mentoring and Coaching.

www.csir.co.za/enews/june/corporate/pdfs/Mentoring.pdf

(Accessed 15 March 2014).

Russell, D. 2016. Mechatronics Education: Meeting Future Need. In Mechatronic Futures 239 - 253. Springer, Cham.

https://doi.org/10.1007/978-3-319-32156-1 15

Seamus, G., R. Alan \& L. Shane 2018. Meeting the Needs of Industry in Smart Manufacture - The Definition of a New Profession and a Case Study in Providing the Required Skillset. Procedia Manufacturing 17: 262 - 269. https://doi.org/10.1016/j.promfg.2018.10.045

Simpson, E., D. Bradley \& P. Hehenberger, September 2018. Innovation and Failure in Mechatronics Design Education. In Mechatronics 2018 -Reinventing Mechatronics: $16^{\text {th }}$ Mechatronics Forum International Conference, 17 - 24 September 2018. University of Strathclyde Publishing.

Smith, M.K. 2000. Curriculum Theory and Practice. The Encyclopedia of Informal Education.

http://www.fnbaldeo.com/EDCI\%20547\%20-

\%20March\%202018/Resource\%20Materials/Curriculum\%20Theory\%2 0and\%20Practice.pdf

Trentino. 2012. New Boost for Mechatronic Cluster. http://www.investintrentino.it/News/New-boost-for-Mechatronic-cluster Tutunji, T.A., M. Jumah, Y. Hosamel-Deen \& S.A. Rabbo 2007. Mechatronics Curriculum Development at Philadelphia University in Jordan. Mechatronics 17: $65-71$.

https://doi.org/10.1016/j.mechatronics.2006.03.009

University of Stellenbosch 2013. Mechatronic Engineering. 
https://www.mecheng.sun.ac.za/undergraduate-programmes/prospectiveundergraduate/mechatronic-engineering/ (Accessed 2 August 2013.)

Venuvinod, P.K. \& P.N. Reddy 2002. Future Trends in Mechatronic Engineering.

http://www.tecinnovent.com/trendsmechatronicengednvinodpnr02.pdf

Venuvinod, P.K., L.W. Chan, D.N. Leung \& K. RaoK 1993. Development of the First Mechatronic Engineering Degree Course in the Far East. Mechatronic 3: $537-541$.

https://doi.org/10.1016/0957-4158(93)90022-T

Wolff, K.E. 2013. 'Reservoirs' and 'Repertoires': Epistemological and Discursive Complexities in Multidisciplinary Engineering Practice. Journal of Academic Writing 3,1: 84 - 94.

https://doi.org/10.18552/joaw.v3i1.94

Quraisha Dawood Independent Institute of Education Varsity College Durban, South Africa Qdawood@varsitycollege.co.za

Professor Mariam Seedat-Khan CCS University of KwaZulu-Natal Howard College Campus Department of Sociology Durban, South Africa Seedatm@ukzn.ac.za 